\title{
An expert-assisted citizen science program involving agricultural high schools provides national patterns on bee species assemblages
}

\author{
Violette Le Féon ${ }^{1,2} \cdot$ Mickaël Henry $^{1,2} \cdot$ Laurent Guilbaud $^{1,2}$. \\ Clémentine Coiffait-Gombault ${ }^{1,2} \cdot$ Eric Dufrêne $^{3} \cdot$ Emilie Kolodziejczyk $^{4,5}$. \\ Michael Kuhlmann $^{6} \cdot$ Fabrice Requier $^{1,2} \cdot$ Bernard E. Vaissière $^{1,2}$
}

Received: 15 March 2016 / Accepted: 4 October 2016 / Published online: 12 October 2016

(C) The Author(s) 2016. This article is published with open access at Springerlink.com

\begin{abstract}
Ecology studies often require large datasets. The benefits of citizen science for collecting such datasets include the extension of spatial and temporal scales, and cost reduction. In classical citizen science, citizens collect data and send them directly to scientists. This may not be possible for the many biological groups for which specimen identification is difficult and requires highlevel expertise. Here we report the results of an expertassisted citizen science program where teachers from 20 French agricultural high schools collected bees, which were identified to species level by a panel of expert bee taxonomists. Overall the dataset included 70 collections (year $\times$ sampling site combinations) that resulted in 4574 specimens belonging to 195 species. We analysed this
\end{abstract}

Electronic supplementary material The online version of this article (doi:10.1007/s10841-016-9927-1) contains supplementary material, which is available to authorized users.

Violette Le Féon

violette.lefeon@gmail.com

Bernard E. Vaissière

bernard.vaissiere@inra.fr

1 INRA, UR 406 Abeilles et Environnement, Site Agroparc, 84914 Avignon, France

2 UMT PrADE, Site Agroparc, 84914 Avignon, France

3 Observatoire des Abeilles, 9 allée des Pins, Malassis, 91470 Forges-les-Bains, France

4 CEZ - Bergerie Nationale, Parc du Château, CS 40609, 78514 Rambouillet Cedex, France

5 Aménagement de l'espace STAV, Lycée agricole Reinach, 73290 La Motte Servolex, France

6 Zoological Museum of Kiel University, Hegewischstraße 3, 24105 Kiel, Germany dataset using data freely available at a national scale on agriculture intensity and landscape composition. We found that species richness increased with increasing proportion of herbaceous semi-natural elements; species dominance decreased with increasing crop diversity; the proportion of above ground nesting species and specimens increased as the intensity of agricultural practices decreased. Comparing the results obtained with identification to species level and those obtained with higher taxa or parataxonomic approaches, we found that the loss of taxonomic resolution resulted in the non-significance of some results on the effects of environmental variables on bee assemblage-level attributes. Our study suggests that identification to species level is of great importance to detect the effects of global change on bees and that an expert-assisted citizen science paradigm could provide relevant results to guide conservation measures at a national scale.

Keywords Agriculture intensity - Dominance · Ecological traits · Landscape composition ·

Lasioglossum spp. ' Standardized citizen data

\section{Introduction}

Data on species distribution provide baseline information in biogeography and population trend studies (Kerr et al. 2007; Cardoso et al. 2011). In the context of global change, these data have gained importance in the assessment of the effects of anthropogenic disturbances on biodiversity (Butchart et al. 2010). Such studies often require large datasets that cannot be gathered by individual research teams (Devictor et al. 2010; Dickinson et al. 2010). For centuries, amateur naturalists have collected data on species occurrence (MillerRushing et al. 2012; Pocock et al. 2015). In recent years, 
citizen science programs have flourished in ecology, with many benefits such as an extension of spatial and temporal scales (including data collection on private areas such as gardens), time and cost reduction, and reconnection of people with nature leading to an increasing public awareness about environmental issues (Bonney et al. 2009; Devictor et al. 2010; Dickinson et al. 2010; Birkin and Goulson 2015; van der Wal et al. 2015).

Birds and butterflies dominate as study groups in citizen science (Schmeller et al. 2009; Devictor et al. 2010; Dickinson et al. 2010; Roy et al. 2015). In these groups, comprehensive identification tools exist and identification to species level is relatively easy. For many other biological groups, identification to species level is virtually impossible without collecting specimens and identifying them using both reference collections and relevant literature. In those cases, the alternatives to identification to species level by citizen scientists are the identification at higher taxonomic (e.g., genus, family) or at parataxonomic levels (sensu Krell 2004) sometimes based on photographs (Deguines et al. 2012; Casanovas et al. 2014) or the help of experts to reach the species level (Gardiner et al. 2012 for the Coccinellidae).

Bees (Hymenoptera: Apoidea) constitute one of these species-rich and diverse groups (926 species recorded in continental France, Kuhlmann et al. 2015) for which identification to species level is inherently challenging. Moreover, limited and sparse identification tools are available (Brown and Paxton 2009; Patiny et al. 2009). The identification to species level is therefore dependent on the help of a panel of expert bee taxonomists, i.e. persons recognised as an authority in their field, typically academics or museum scientists but sometimes also non-academics with a deep interest in the natural history of a particular taxon. Bees have become the focus of much interest over the last decade because of concerns about species decline and the expected consequences on wild plant and crop pollination (Steffan-Dewenter et al. 2005; Biesmeijer et al. 2006; González-Varo et al. 2013; Ollerton et al. 2014; Goulson et al. 2015; Garibaldi et al. 2016). Although long-term recording allowed the assessment of species trends in some countries (see e.g. Biesmeijer et al. 2006; Ollerton et al. 2014; Thomas et al. 2015 for British studies based on bee records collected by the UK BWARS - Bees Wasps \& Ants Recording Society), data are severely lacking regarding bee species distribution (Brown and Paxton 2009; Patiny et al. 2009; Nieto et al. 2014) and community composition (Winfree et al. 2011) to understand the effects of global change on bee populations and thereby be able to design meaningful conservation strategies (Cardoso et al. 2011).

Our overall objective was to test an expert-assisted citizen science paradigm to study the effects of global change on bee species assemblages in agricultural landscapes over a large area. In the classical citizen science paradigm, citizens collect data and send them directly to scientists. In the expert-assisted citizen science paradigm, citizens provide material to experts that analyse it (e.g., identification of specimens to species level) and these experts send the data to scientists (Fig. 1). We here report the first results of an ongoing citizen science program where a specific group of participants, namely teachers from agricultural high schools in France, conducted standardized surveys of bees, which were then identified to species level by expert bee taxonomists. This approach combines the benefits of data collection by a national network of volunteers and those of data reliability to species level provided by the contribution of experts. We first study the effects of agriculture intensity and landscape composition on bee species assemblages. Then we compare the results obtained with the species level (i.e. with the help of experts) to those obtained with higher taxa or parataxonomic approaches (i.e. without the help of experts and participants being able to provide data directly to scientists). We hypothesise that (1) bee taxonomic richness will decrease, and inversely dominance (the proportion of the most abundant taxon) will increase, with increasing agriculture intensity and decreasing amount of semi-natural elements; (2) increasing agriculture intensity and decreasing amount of semi-natural elements will influence the functional composition of bee assemblages, with parasitic, oligolectic, and above ground nesting species being negatively affected; (3) the loss of the species level resolution will result in the nonsignificance of some results on the effects of environmental variables on bee assemblage-level attributes.

\section{Methods}

\section{Study sites}

From 2009 onwards, volunteer biology and ecology teachers from French agricultural high schools were asked to collect wild bees following a standardized protocol. Contributions came from most continental French areas with land cover dominated by agricultural land-use (Fig. 2). The 20 contributing schools were located in rural areas and comprised a farm for educational purposes. They encompassed the diversity of situations currently occurring in French agriculture, in terms of production types (farms devoted to annual or perennial crops, to livestock, or mixed farming systems), agriculture intensity, and relative surface of semi-natural elements in the landscape (see "Environmental variables").

\section{Bee sampling and identification}

Netting, pan traps and trap nests are common methods used to sample bees (Westphal et al. 2008). In this study, 


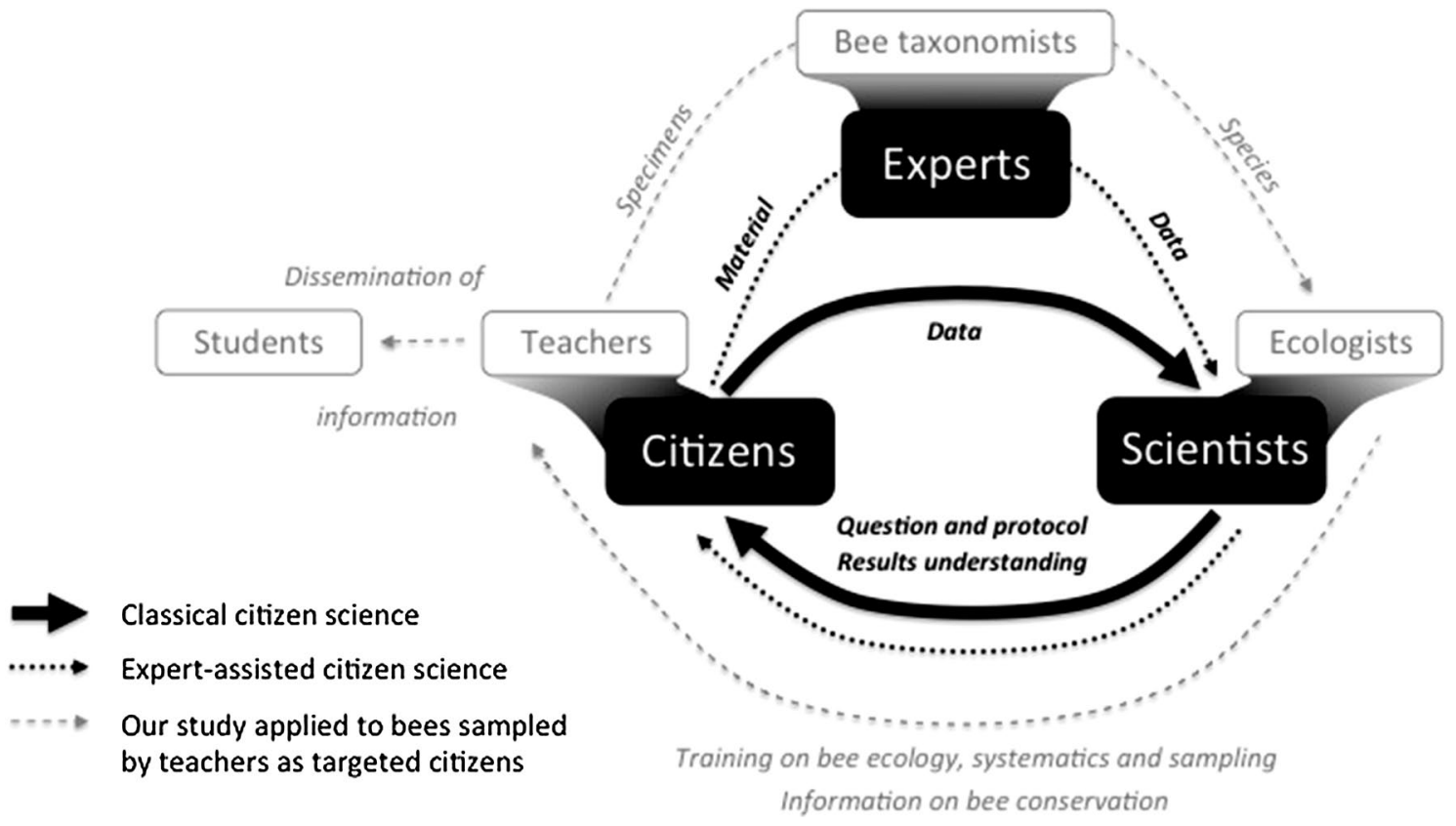

Fig. 1 Conceptual framework (adapted from Devictor et al. 2010) of the expert-assisted citizen science paradigm (in black). In the classical citizen science paradigm, citizens collect data that are directly sent to scientists. Classical citizen science requires various skill levels but the identification of biological material at a useful level remains doable with common tools (e.g., books, identification keys). In the expertassisted citizen science paradigm, citizens provide the material (e.g., specimens, photographs) to experts that analyse it (e.g., identification of specimens to species level) and these experts send the data to scientists. The involvement of experts is required when identification for the biological group under study is difficult, requires high level of knowledge and experience, and specific tools (e.g., reference collection). Grey elements illustrate the expert-assisted targeted citizen science program described in this paper we chose pan trapping as a standardized sampling method because: (1) this method is particularly well suited to minimize collector biases (Westphal et al. 2008). These biases could have been considerable with netting in our case given the high number of participants, most of which had no prior entomological experience; (2) pan traps can provide reliable data to assess the overall species richness of a study site even though they are known to be poor in capturing species of genera like Bombus and Colletes (Roulston et al. 2007; Westphal et al. 2008; Wilson et al. 2008, but see; Wood et al. 2015); (3) pan traps are cheap and simple to use (LeBuhn et al. 2013). Traps were made of 500-ml plastic bowls that were sprayed inside with a UV-reflecting paint and were mounted on a wooden pole. One disadvantage of pan traps is that their effectiveness is affected by the local environmental context, in particular the local floral resource availability (Westphal et al. 2008; Wilson et al. 2008; Baum and Wallen 2011). To cope with this bias, traps were placed near flowers when there were flowers at the site (flowers were not necessarily present all year long), at a height slightly above that of the average vegetation, and in the sun inasmuch as was possible so as to be clearly visible. A sampling site consisted of a set of three pan traps (a blue, a white, and a yellow) and sampling was initiated by filling each bowl with $400 \mathrm{ml}$ of water with a drop of detergent. Identical pan traps were supplied to all schools by INRA
(Institut National de la Recherche Agronomique), Avignon, France, the scientific coordinator of the program. Participants chose the number of sampling sites (ranging from one to seven per school, mean \pm S.E. $2.25 \pm 0.35$ ) and their location in the school. Participants were asked to make, under suitable weather conditions (minimum of $15^{\circ} \mathrm{C}$, low wind, no rain), one 24-h capture session each month from March to October, in order to obtain an overall assessment of the bee assemblage composition over the whole flying season (Banaszak et al. 2014). In practice, some participants could not carry out the required number of sessions or others made more than one session in a month. In order to derive meaningful assemblage summary statistics, we discarded the four annual datasets made up of $<5$ sampling months. This resulted in 70 sampling site $\times$ year combinations, 6 in 2009, 24 in 2010, and 40 in 2011 (Online Resource 1). For the sake of simplicity, we further defined a collection as the captures made at a given sampling site during a given year. The number of sampling dates (that is 24-h sessions) for a collection ranged from 5 to 12 . Participants were asked to keep the same number and the same location for sampling sites across years, but in practice these parameters changed somewhat as some locations became inaccessible, or enthusiastic participants wanted to increase their sampling effort after their first year in the project. We totalled 45 different sampling sites over the 20 schools, which were sampled 


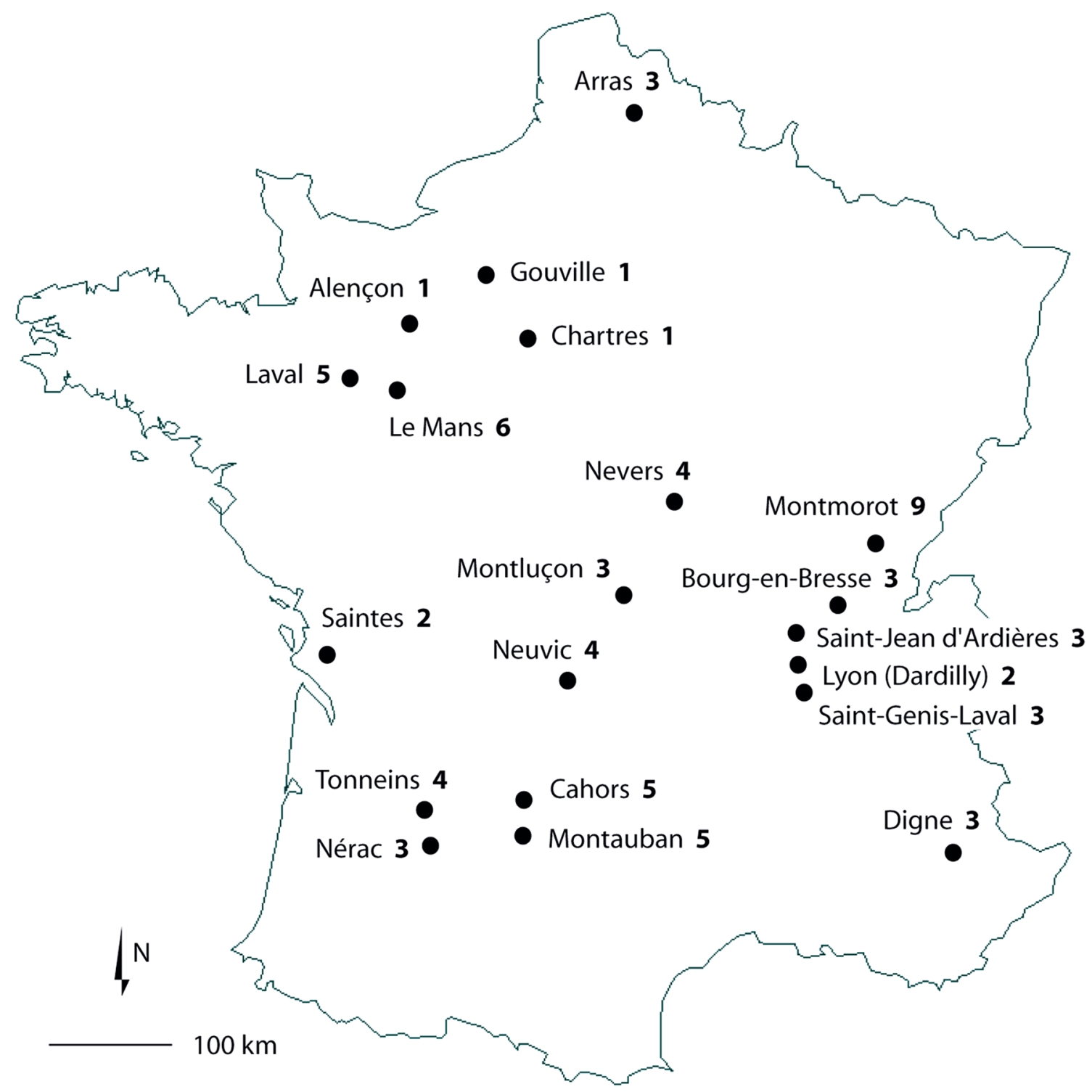

Fig. 2 Location of the 20 agricultural high schools involved in the study in continental France. The number of collections (sampling site $\times$ year combinations $)$ is given for each school $(\mathrm{n}=70$ collections in total)

over 1, 2, or the 3 years $(2009,2010$, and 2011). These 45 sampling sites were located in 25 different municipalities (local administrative units).

At the onset of the program, all the participants followed a 5-day course on bee biology and systematics provided by scientists and bee experts, and which included training on techniques to prepare specimens recovered from pan traps and identification to genus level. Afterwards, all bees caught during the program were pinned, labelled and pre-identified to genus by the teachers, centralized and double-checked at INRA Avignon, and then sent to a panel of expert bee taxonomists to be identified to species level. Specimens were deposited in the collection of INRA Avignon and, for the most common species, in a reference collection in each participating school. Taxonomy followed the nomenclature of
Kuhlmann et al. (2015). Honey bees (Apis mellifera) were caught, but this species was not considered as its abundance is largely determined by beekeeping. Therefore we use "bees" synonymously with "wild bees" in the following.

\section{Assemblage-level attributes}

For each collection, we calculated two sets of attributes. The first set required the identification of bee specimens to species level, i.e. with the help of expert bee taxonomists (expert-assisted citizen science paradigm). The attributes of the second set did not require the identification to species level and could be obtained by teachers alone, provided that they received the course on bee identification to genus level (classical citizen science paradigm). 
First set of attributes (expert-assisted citizen science paradigm)

- Species richness: This is the number of species caught over 1 year at the sampling site;

- Species dominance: This is the proportion of the most abundant species (also known as Berger-Parker index);

- Ecological traits: Each species was described according to three ecological traits that have been shown to be important to determine the response of bees to environmental disturbances (e.g., Moretti et al. 2009; Williams et al. 2010; Winfree et al. 2011; Sheffield et al. 2013; Rader et al. 2014; Kremen and M'Gonigle 2015): reproductive strategy, trophic specialization, and nesting behaviour. Information was compiled from the literature (Westrich 1989; Amiet et al. 1999, 2001, 2004, 2007, 2010; Michener 2007). Occasionally, ecological traits can be inferred from the genus (e.g., all Nomada species are parasitic), but the species level is usually necessary to determine ecological traits. For examples, very similar (cryptic) species can have opposite behaviour (for example very similar Bombus species are either parasitic or non-parasitic) or a single genus may comprise both oligolectic and polylectic species (e.g., the genus Andrena).

For the reproductive strategy, we separated nonparasitic from parasitic species and the subsequent classes were made only for non-parasitic species. For trophic specialisation regarding pollen use, we distinguished between oligolectic species collecting pollen on plant species from a single family and polylectic species collecting pollen on several plant families. For nesting behaviour, species nesting below ground were separated from those nesting above ground in cavities (e.g., plant stems, wood holes, snail shells). Then, we calculated the proportion of species and the proportion of specimens for modalities that have been shown to be negatively affected by environmental disturbances, that is "parasitic", "oligolectic", and "above ground nesting" modalities (Biesmeijer et al. 2006; Williams et al. 2010; Rader et al. 2014).

\section{Second set of attributes (classical citizen science paradigm)}

- Genus richness: This is the number of genera caught over 1 year at the sampling site;

- Parataxonomic richness, with three subdivisions according to body size: We used this attribute to test whether the "classical citizen science" approach could be improved by further subdividing genera using body size. Doing this, we obtained parataxonomic units, i.e. based on external morphology (sensu Krell 2004). This additional subdivision reduces the taxonomic resolution that is lost when using genera instead of species (van Rijn et al. 2015). The inter-tegular distance (ITD, the distance between the two insertion points of the wings) is often used as a proxy for body size in bees (Cane 1987). ITD values for our dataset were obtained from Fortel et al. (2014). Each genus was subdivided into three size classes: ITD $<2.6,2.6-4.6$, and $>4.6 \mathrm{~mm}$. We defined the parataxonomic richness as the number of parataxonomic units caught over 1 year at the sampling site;

- Parataxonomic richness, with seven subdivisions according to body size: This is the same approach as above but instead of three, seven subdivisions were considered following van Rijn et al. (2015): ITD $<1,1-1.5$, $1.5-2,2-2.5,2.5-3,3-3.5$, and $>3.5 \mathrm{~mm}$;

- Genus dominance: This is the proportion of specimens for the most abundant genus;

- Parataxonomic dominance, with three subdivisions according to body size: This is the proportion of the most abundant parataxonomic unit when considering three ITD subdivisions;

- Parataxonomic dominance, with seven subdivisions according to body size: This is the proportion of the most abundant parataxonomic unit when considering seven ITD subdivisions.

\section{Environmental variables}

We related our ecological dataset to environmental data freely available at the national scale. We used information derived from the High Nature Value (HNV) indicator regarding agriculture intensity and the Corine Land Cover (CLC) database regarding the landscape composition.

\section{Agriculture intensity at the municipality level}

We assigned each of the 25 municipalities to four variables regarding agriculture intensity: "Crop diversity" (a proxy for the crop rotation system), "Extensive farming practices" (an estimation of pesticide, mineral fertilizers, and irrigation use), "Landscape elements" (an estimation of the relative area of semi-natural elements), and an overall index of agriculture intensity. The three first variables were scored from 0 (low crop diversity, high input level, and low availability of semi-natural elements, respectively) to 10 . The overall intensity index was obtained in summing the three scores (with low index values corresponding to high agriculture intensity). These four variables were derived from the French HNV dataset. European Union countries have been required to identify HNV farmlands, i.e. areas that include semi-natural elements, low-intensity farming and diverse, 
small-scale mosaics of land-use types. The details of how to implement this indicator were at the discretion of each state (CEC 2006). In France, indicators aggregating statistics of agricultural holdings were calculated at the municipality level (Pointereau et al. 2010; Doxa et al. 2012; Deguines et al. 2014). The national mean for the overall intensity index was 12.20 (S.E. $\pm 1.8 \times 10^{-4}$ ) and its values ranged from 1 to 30 when considering all 36,027 French municipalities. In our dataset, the average value was nearly the same as the national average (mean \pm S.E. $12.42 \pm 0.77)$ and the values ranged from 4.92 to 25.12 .

\section{Proportion of semi-natural elements at the landscape scale}

To examine the effect of landscape composition, we obtained land cover data from the CLC 2006 database (Bossard et al. 2006). CLC is a geo-referenced database including the main habitats for the European Union countries in contiguous polygons classified according to 44 different landcover categories in the finest classification. We quantified the landscape composition in 100 and $500 \mathrm{~m}$ radius windows centred on sampling sites by using the geographical information system package ArcGIS 10.1 (ESRI 2012). We chose these window sizes as relevant scales for flight and foraging distances in bees (Gathmann and Tscharntke 2002). For each sampling site, we calculated the proportion of semi-natural herbaceous elements. In our case, this variable included the CLC classes "Pastures", "Complex cultivation patterns", "Land principally occupied by agriculture, with significant areas of natural vegetation", "Moors and heathland", and "Transitional woodland-shrub". The proportion of herbaceous semi-natural elements ranged from 0 to $100 \%$ (mean \pm S.E. $37.7 \pm 5.3)$ in $100 \mathrm{~m}$ radius windows and from 0 to $99.05 \%($ mean \pm S.E. $39.9 \pm 3.3)$ in $500 \mathrm{~m}$ radius windows. We also considered a variable including both herbaceous and woody elements (forests), but models returned non-significant results (not shown) and so they were not considered further.

\section{Statistical analyses}

The assessment of assemblage-level responses to environmental variables was performed within a generalized linear mixed model (GLMM) framework in order to cope with the non-independence of surveys carried out by the same contributing school at different sampling sites and repeated over several years. We therefore parameterized GLMMs with assemblage-level attributes as response variables, environmental variables as fixed effect candidate covariates and school, municipality and sampling site identities as a suite of hierarchically nested random grouping variables. Normality requirements of continuous data were tested using the Shapiro-Wilk statistics. Model residuals were further inspected against fitted values to ensure residual normality and homoscedasticity requirements were fulfilled. Models were fitted using the maximum log-likelihood criteria, and the significance of environmental variables was assessed $a$ posteriori using likelihood ratio deletion tests. When necessary, unequal sampling effort (number of sampling dates in an annual survey) was accounted for by specifying sampling effort as an offset term. This was required for analyses of species, genus and parataxonomic richness, but deemed unnecessary for dominance attributes and ecological trait proportions. Analyses were conducted using R software version 3.1.1 (R Core Team 2014), using the package lme4 (Bates et al. 2014).

\section{Results}

\section{Overall taxonomic and functional composition of the bee dataset}

Participants collected a total of 4574 specimens representing 195 species (Online Resources 1, 2). The family Halictidae largely dominated the captures $(73.3 \%$ of specimens and $31.3 \%$ of species), followed by Andrenidae $(16.2 \%$ of specimens and $23.6 \%$ of species) and Apidae $(6.8 \%$ of specimens and $22.6 \%$ of species). Colletidae, Megachilidae and Melittidae all represented $<2 \%$ of the specimens and $6.1,15.4$, and $1.0 \%$ of the species, respectively. The genus Lasioglossum was the most abundant, representing 55.4\% of the specimens. The genus Andrena represented $15.6 \%$ of the specimens, but it was the most species rich with 43 species (vs. 36 species of Lasioglossum). Lasioglossum malachurum was a superabundant species, representing $20.0 \%$ of all specimens. It was detected in $88.6 \%$ of collections and dominated in $45.7 \%$. The second most abundant species, L. morio, represented $5.7 \%$ of specimens, was detected in $67.1 \%$ of collections and dominated in $11.4 \%$. These two species were followed by four species of Halictidae (Lasioglossum glabriusculum, L. pauxillum, Halictus scabiosae, H. tumulorum), each making between 4 and $5 \%$ of the specimens. The following species, i.e. the most abundant nonhalictid species, was Andrena flavipes that made-up 3.1\% of specimens and was present in $52.9 \%$ of collections.

Regarding the ecological traits, 30 parasitic and 165 nonparasitic species were caught. These non-parasitic species included 47 above ground versus 116 below ground nesting species (information was missing for two species), and 36 oligolectic versus 120 polylectic species (with diet information lacking for nine species). All seven most abundant species (species that accounted for more than $3 \%$ of the total abundance) were non-parasitic, below ground nesting, polylectic, and social bees (with the exception of $H$. scabiosae and $A$. flavipes that are solitary). 
Regarding richness attributes that could be obtained by the teachers without the help of expert bee taxonomists (classical citizen science paradigm), the dataset comprised 25 genera, 31 parataxonomic units when considering three subdivisions according to body size, and 49 parataxonomic units when considering seven subdivisions.

\section{Taxonomic and functional composition at the assemblage level}

The number of species in a collection ranged from 7 to 34 (mean \pm S.E. 17.2 \pm 0.6 ). The number of specimens ranged from 20 to 293 (mean \pm S.E. $65.3 \pm 6.0)$. The proportion of parasitic, oligolectic, and above ground nesting species represented on average $5.9( \pm 0.8), 11.1( \pm 1.0)$, and $9.3 \%( \pm 1.1)$ of the total species richness, and $2.9( \pm 0.5), 7.3( \pm 1.1)$, and $3.0 \%( \pm 3.9)$ of the total abundance, respectively.

The dominant species made-up between 11.5 and $71.1 \%$ of the total abundance (mean \pm S.E. $30.8 \pm 1.5$ ), and it was always a non-parasitic and below ground nesting species. In most cases, it was social (54 collections) and polylectic (65 collections). Oligolectic species were dominant in some rare cases (Dasypoda hirtipes and Tetralonia malvae both in two collections). L. malachurum dominated in 32 collections, and L. morio, H. scabiosae and H. tumulorum dominated in 8,5 and 5 collections, respectively.

The dominant genus made-up between 28.2 and $95.4 \%$ of the total abundance (mean \pm S.E. $54.3 \pm 1.9)$. The genus Lasiglossum dominated in 53 collections.

\section{Comparison between the expert-assisted and the classical citizen science paradigms when relating bee assemblage-level attributes and environmental variables}

Species richness increased with the increasing proportion of herbaceous semi-natural elements in $100 \mathrm{~m}$ radius windows (Table 1; Fig. 3a). Species dominance decreased with increasing crop diversity (Fig. 3b). The proportion of above ground nesting species and specimens increased with decreasing agriculture intensity (significant only for the proportion of specimens), with increasing crop diversity, and when the intensity of fertilizer and pesticide use decreased (Fig. 3c). There was no significant relationship between attributes regarding either parasitic status or trophic specialization with environmental variables (Table 1).

Considering the attributes obtained without the help of expert bee taxonomists (classical citizen science paradigm), there was no significant relationship between genus and parataxonomic richness and environmental variables (Table 2; Fig. 4). The genus dominance decreased with decreasing agriculture intensity, with increasing crop diversity (Fig. 3d) and when the intensity of fertilizer and pesticide use decreased. Similarly, the proportion of the most abundant parataxonomic unit, when considering three subdivisions according to body size, decreased with decreasing agriculture intensity and with increasing crop diversity (Table 2).

\section{Discussion}

We present the results of a monitoring program conducted at the national scale and which involved a targeted group of citizens (teachers from agricultural high schools), researchers, and expert bee taxonomists (Fig. 1). Our dataset provided general patterns regarding functional and taxonomic composition of bee assemblages, as well as responses of bees to agriculture intensity and landscape composition. Comparing the results obtained through expert-assisted and classical citizen science paradigms, i.e. the results with identification to species level and those obtained with higher taxa or parataxonomic approaches, we found that the loss of taxonomic resolution resulted in the non-significance of some results on the effects of environmental variables on bee assemblage-level attributes.

\section{Taxonomic and functional composition of assemblages}

Over 3 years of sampling in 20 agricultural high schools and 4574 individuals caught, this program provided information on the distribution of 195 species, representing $21.1 \%$ of the 926 species recorded in continental France (Kuhlmann et al. 2015). The dataset did not include threatened species at the European level (Nieto et al. 2014), but some species were uncommon at the national scale such as Andrena apicata, A. hattorfiana, and $A$. ventricosa (David Genoud, pers. comm.). Although the 45 sampling sites encompassed a great diversity of climate, agricultural, landscape and local scale contexts, we found some recurrent features across sites and years. The dominance of Halictidae, Lasioglossum sp. in particular, appeared as a general trend. This feature has been observed in various places across the world [e.g., Marini et al. (2012) in Italy; Morandin and Kremen (2013) in USA; Fortel et al. (2014) in France; Rader et al. (2014) in New-Zealand; Saunders and Luck (2014) in Australia; Pisanty and Mandelik (2015) in Israel; Le Féon et al. (2016) in Argentina]. These species are especially well caught by pan traps but their high abundance is also observed when bees are sampled by netting (e.g., Rollin et al. 2015). The dominance of Lasioglossum species in bee assemblages may be due to their eusociality (in some species) and their polylecty. Beyond these results at the family and genus levels, our results provide insights on the status of species at the national scale. In particular, Lasioglossum malachurum was virtually omnipresent. Such information on the identity of 
Table 1 Results of the generalized linear mixed models for the assemblage-level attributes based on the identification of bee specimens to species level (i.e. that required the help of expert bee taxonomists)

\begin{tabular}{|c|c|c|c|c|}
\hline $\begin{array}{l}\text { Assemblage-level } \\
\text { attribute }\end{array}$ & Environmental variable & Coefficient estimate \pm S.E. & $F$ & $P$ \\
\hline \multirow[t]{6}{*}{ Species richness } & HNV overall index & $-0.051 \pm 0.146$ & 0.120 & 0.729 \\
\hline & Crop diversity & $0.089 \pm 0.466$ & 0.035 & 0.852 \\
\hline & Extensive farming practices & $-0.425 \pm 0.425$ & 0.977 & 0.323 \\
\hline & Semi-natural element availability & $-0.034 \pm 0.256$ & 0.017 & 0.895 \\
\hline & Proportion of semi-natural elements $100 \mathrm{~m}$ & $0.033 \pm 0.016$ & 3.934 & $0.047^{*}$ \\
\hline & Proportion of semi-natural elements $500 \mathrm{~m}$ & $0.034 \pm 0.028$ & 1.396 & 0.237 \\
\hline \multirow[t]{6}{*}{ Species dominance } & HNV overall index & $-0.026 \pm 0.013$ & 3.430 & 0.064 \\
\hline & Crop diversity & $-0.097 \pm 0.045$ & 4.443 & $\mathbf{0 . 0 3 5}^{*}$ \\
\hline & Extensive farming practices & $-0.068 \pm 0.044$ & 2.302 & 0.129 \\
\hline & Semi-natural element availability & $-0.032 \pm 0.024$ & 1.686 & 0.194 \\
\hline & Proportion of semi-natural elements $100 \mathrm{~m}$ & $0.003 \pm 0.002$ & 1.860 & 0.173 \\
\hline & Proportion of semi-natural elements $500 \mathrm{~m}$ & $0.001 \pm 0.003$ & 0.068 & 0.794 \\
\hline \multirow{6}{*}{$\begin{array}{l}\text { Proportion of parasitic } \\
\text { specimens }\end{array}$} & HNV overall index & $0.036 \pm 0.039$ & 0.881 & 0.348 \\
\hline & Crop diversity & $0.221 \pm 0.124$ & 3.107 & 0.078 \\
\hline & Extensive farming practices & $0.026 \pm 0.119$ & 0.048 & 0.826 \\
\hline & Semi-natural element availability & $0.0428 \pm 0.069$ & 0.386 & 0.535 \\
\hline & Proportion of semi-natural elements $100 \mathrm{~m}$ & $-0.010 \pm 0.005$ & 2.796 & 0.094 \\
\hline & Proportion of semi-natural elements $500 \mathrm{~m}$ & $-0.013 \pm 0.013$ & 0.932 & 0.334 \\
\hline \multirow{6}{*}{$\begin{array}{l}\text { Proportion of parasitic } \\
\text { species }\end{array}$} & HNV overall index & $0.005 \pm 0.027$ & 0.037 & 0.848 \\
\hline & Crop diversity & $0.102 \pm 0.088$ & 1.382 & 0.240 \\
\hline & Extensive farming practices & $-0.042 \pm 0.084$ & 0.245 & 0.620 \\
\hline & Semi-natural element availability & $-0.001 \pm 0.048$ & 0.001 & 0.976 \\
\hline & Proportion of semi-natural elements $100 \mathrm{~m}$ & $-0.004 \pm 0.004$ & 1.381 & 0.240 \\
\hline & Proportion of semi-natural elements $500 \mathrm{~m}$ & $-0.006 \pm 0.007$ & 0.713 & 0.398 \\
\hline \multirow{6}{*}{$\begin{array}{l}\text { Proportion of oligolectic } \\
\text { specimens }\end{array}$} & HNV overall index & $-0.051 \pm 0.002$ & 1.496 & 0.221 \\
\hline & Crop diversity & $-0.090 \pm 0.114$ & 0.584 & 0.445 \\
\hline & Extensive farming practices & $-0.058 \pm 0.112$ & 0.255 & 0.614 \\
\hline & Semi-natural element availability & $-0.098 \pm 0.069$ & 1.843 & 0.175 \\
\hline & Proportion of semi-natural elements $100 \mathrm{~m}$ & $-0.007 \pm 0.005$ & 1.975 & 0.160 \\
\hline & Proportion of semi-natural elements $500 \mathrm{~m}$ & $-0.001 \pm 0.007$ & 0.008 & 0.927 \\
\hline \multirow{6}{*}{$\begin{array}{l}\text { Proportion of oligolectic } \\
\text { species }\end{array}$} & HNV overall index & $-0.033 \pm 0.017$ & 2.827 & 0.093 \\
\hline & Crop diversity & $-0.096 \pm 0.053$ & 2.675 & 0.102 \\
\hline & Extensive farming practices & $-0.087 \pm 0.058$ & 2.186 & 0.139 \\
\hline & Semi-natural element availability & $-0.036 \pm 0.036$ & 1.028 & 0.310 \\
\hline & Proportion of semi-natural elements $100 \mathrm{~m}$ & $0.0003 \pm 0.002$ & 0.015 & 0.901 \\
\hline & Proportion of semi-natural elements $500 \mathrm{~m}$ & $0.002 \pm 0.004$ & 0.319 & 0.572 \\
\hline \multirow{6}{*}{$\begin{array}{l}\text { Proportion of above } \\
\text { ground nesting } \\
\text { specimens }\end{array}$} & HNV overall index & $0.082 \pm 0.038$ & 4.712 & $0.030 *$ \\
\hline & Crop diversity & $0.293 \pm 0.113$ & 6.401 & $0.011 *$ \\
\hline & Extensive farming practices & $0.319 \pm 0.098$ & 10.154 & $0.001 * *$ \\
\hline & Semi-natural element availability & $0.046 \pm 0.073$ & 0.413 & 0.521 \\
\hline & Proportion of semi-natural elements $100 \mathrm{~m}$ & $-0.003 \pm 0.004$ & 0.426 & 0.514 \\
\hline & Proportion of semi-natural elements $500 \mathrm{~m}$ & $0.0005 \pm 0.007$ & 0.004 & 0.947 \\
\hline
\end{tabular}


Table 1 (continued)

\begin{tabular}{llcrc}
\hline $\begin{array}{l}\text { Assemblage-level } \\
\text { attribute }\end{array}$ & Environmental variable & Coefficient estimate \pm S.E. & $F$ & $P$ \\
\hline $\begin{array}{l}\text { Proportion of above } \\
\text { ground nesting species }\end{array}$ & HNV overall index & & \\
& Crop diversity & $0.053 \pm 0.028$ & 3.647 & 0.056 \\
& Extensive farming practices & $0.204 \pm 0.082$ & 5.603 & $\mathbf{0 . 0 1 8 *}$ \\
& Semi-natural element availability & $0.209 \pm 0.064$ & 0.660 & 0.093 \\
& Proportion of semi-natural elements $100 \mathrm{~m}$ & $0.016 \pm 0.053$ & $0.002^{* *}$ \\
& Proportion of semi-natural elements $500 \mathrm{~m}$ & $0.0002 \pm 0.003$ & 0.949 \\
& $0.002 \pm 0.005$ & 0.132 & 0.716 \\
\hline
\end{tabular}

$\mathrm{n}=70$ collections and $d f=1$ in all cases. Significant $P$-values are indicated in bold $\left({ }^{*} P \leq 0.05 ; * * P \leq 0.01\right)$. Models contained an assemblage-level attribute as the response variable, an environmental variable as fixed effects, and school, municipality and sampling site identities as a suite of hierarchically nested random effects. In each case, the first four environmental variables were derived from the High Nature Value (HNV) data and calculated at the municipality level. The proportion of herbaceous semi-natural elements was derived from Corine Land Cover data (2006) and calculated at two spatial scales (100 and $500 \mathrm{~m}$ radius centred on sampling sites)

common versus uncommon species could be trivial regarding well-known groups such as butterflies but remain useful given the lack of knowledge on the distribution and status of bees in France.

From a functional point of view, non-parasitic, polylectic, and below ground nesting species dominated. However parasitic, oligolectic and above ground nesting species each represented a substantial proportion of species and specimens suggesting that farmland on agricultural schools may harbour populations of species with more specific ecological requirements that are also more sensitive to environmental disturbances (Rader et al. 2014).

\section{Comparison between expert-assisted and classical citizen science paradigms}

When comparing the results obtained with identification to species level to the results obtained with higher taxa (genus) or parataxonomic (genus associated with body size subdivisions) approaches, we found that the effect of crop diversity on dominance remained significant when replacing the species level by alternatives that did not require the help of the expert bee taxonomists. On the other hand, the effect of landscape composition on bee richness was not detected when losing the species level resolution.

Previous citizen science programs on bees have provided interesting results on the broad effects of land-use changes (Deguines et al. 2012), on the role of hedgerows for bees (Kremen et al. 2011), and on the nesting ecology and the status of bumblebee species in the UK (Lye et al. 2012). These programs were based on photographic collections (Deguines et al. 2012) and on field observations by trained citizens (Kremen et al. 2011) or members of the public (Lye et al. 2012) and provided information at higher taxonomic levels (genus, family) or at morphospecies or species group levels.
Our study suggests that identification to species level is of great importance for the detection of the effect of environmental variables on bee richness. Furthermore, as many ecological traits are species-specific rather than genus- or family-specific, comprehensive functional approaches cannot be reached without species-level identification (Williams et al. 2010).

\section{Relationships with agriculture intensity and landscape composition}

When ecological data collection occurs at a local scale, information on landscape or agricultural practices may be obtained simultaneously, for example by site mapping from aerial photographs associated to ground-checking and farmer surveys, respectively. For studies at the regional or national scales, this may not be possible and one must seek for environmental data already available (see also Deguines et al. 2012, 2014).

In France, information on agriculture intensity derived from $\mathrm{HNV}$ is given at the municipality level (i.e. $15 \mathrm{~km}^{2}$ on average), which may not be the most relevant scale when considering bee assemblages. Similarly, CLC data are subject to several drawbacks, notably poor spatial definition (the minimum area for an element to be represented is 25 hectares), annual crops pooled together without information on cultivated species (e.g., no information on mass-flowering crops, that can play a major role on bee assemblages, Diekötter et al. 2010; Le Féon et al. 2013).

Despite these major drawbacks, analyses of our empirical dataset gave significant results that confirmed at a national scale those of previous studies. The decrease in species richness associated with decreasing amount of semi-natural elements has been mentioned in several studies (see Winfree et al. 2011 for a review). The particular sensitivity of above ground nesting species to environmental disturbances has also been reported previously (see Williams et al. 2010 for 
(a)

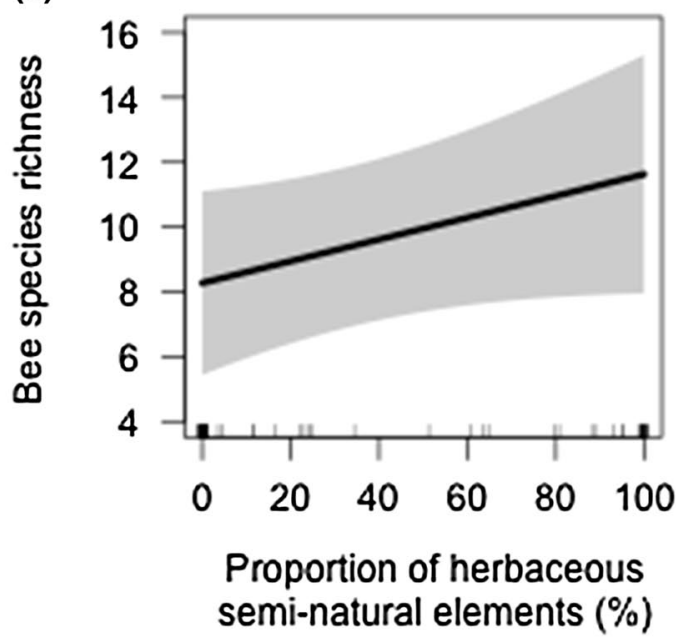

(c)

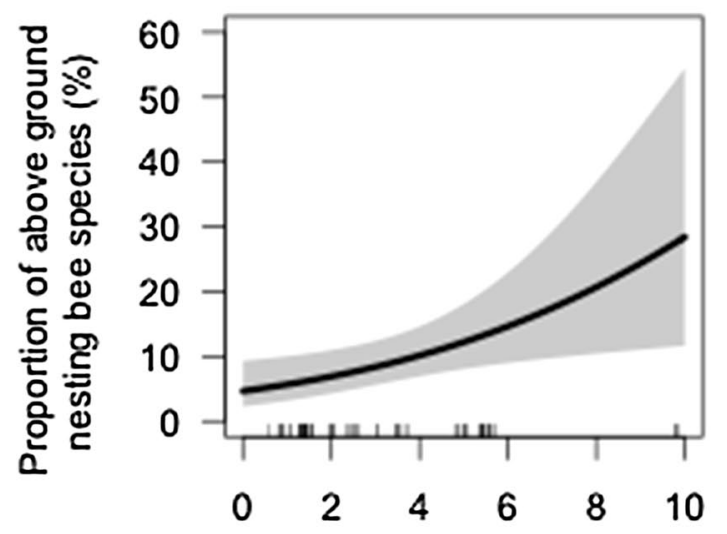

Index of extensive farming practices (b)

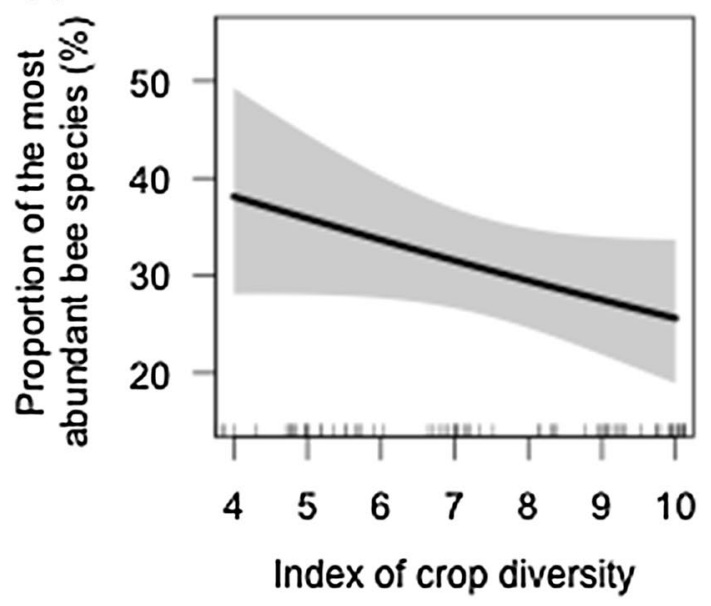

(d)

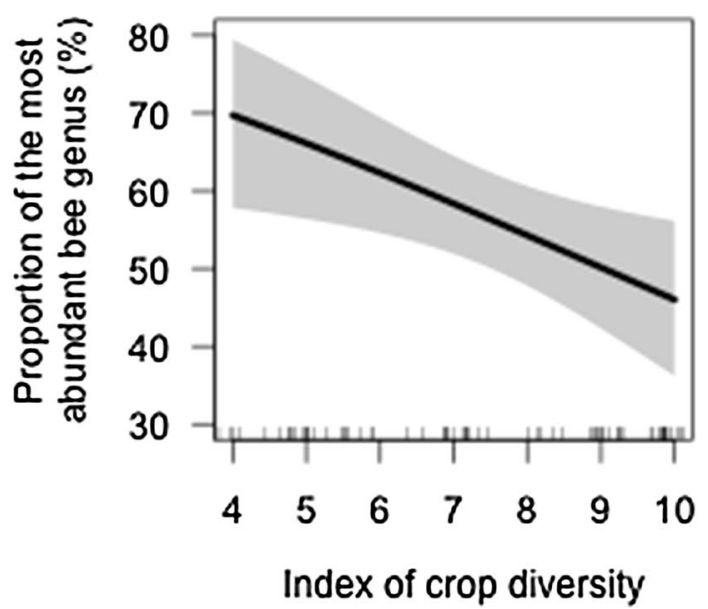

Fig. 3 Relationship between (a) bee species richness and the proportion of herbaceous semi-natural elements in $100 \mathrm{~m}$ radius windows; b the proportion of the most abundant species (species dominance) and the index of crop diversity at the municipality level; $\mathbf{c}$ the proportion of above ground nesting bee species and the index of extensive farming practices; $\mathbf{d}$ the proportion of the most abundant genus (genus dominance) and the index of crop diversity at the municipality level.

a review). Our result may be due to the direct vulnerability of these species to pesticide use (Vaughan et al. 2014) or to the hidden effects associated with agriculture intensification such as the loss of micro-habitats suitable for nest establishment (Kremen and M'Gonigle 2015).

The presence of a few very abundant and many rare species in biotic assemblages is an universal law in ecology (McGill et al. 2007) and, indeed, it has been often noticed in bees (e.g., Williams et al. 2001). However, in various groups, the degree of dominance of the most abundant taxa, as well as their identity, respond to environmental changes, sometimes more rapidly than does species richness (Caruso et al. 2007; Hillebrand et al. 2008; Tolkkinen et al. 2013).
Increasing values of the index of extensive farming practices indicates decreasing pesticide, irrigation, and mineral fertilizer use. Solid lines show significant trends returned by the model predictions. Grey areas indicate $95 \%$ confidence intervals. Small vertical bars along the $x$-axis of each graph show the original values along this axis. Each bar represents a collection (sampling site $\times$ year combination, $\mathrm{n}=70$ collections in total)

This aspect has been little investigated in bees (but see Sheffield et al. 2013; Marini et al. 2014). Thus our results that dominance at the species, genus and parataxonomic levels decreased with crop diversity provides new insights on the influence of agricultural practices on bee assemblages. Indeed, it provides support to the new CAP policy that stresses the importance of crop diversity in order for farmers to be eligible for EU subsidy (European Union 2013).

\section{Conservation implications}

Getting biodiversity data at large spatial and temporal scales is the first stage of any conservation plan (Cardoso 
Table 2 Results of the generalized linear mixed models for the assemblage-level attributes based on the identification of bee specimens at genus level or at parataxonomic levels (i.e. that did not require the help of expert bee taxonomists)

\begin{tabular}{|c|c|c|c|c|}
\hline Assemblage-level attribute & Environmental variable & Coefficient estimate \pm S.E. & $F$ & $P$ \\
\hline \multirow[t]{6}{*}{ Genus richness } & HNV overall index & $-0.029 \pm 0.055$ & 0.257 & 0.612 \\
\hline & Crop diversity & $0.043 \pm 0.179$ & 0.058 & 0.810 \\
\hline & Extensive farming practices & $-0.010 \pm 0.162$ & 0.003 & 0.953 \\
\hline & Semi-natural element availability & $-0.109 \pm 0.094$ & 1.103 & 0.294 \\
\hline & Proportion of semi-natural elements $100 \mathrm{~m}$ & $-0.001 \pm 0.007$ & 0.034 & 0.853 \\
\hline & Proportion of semi-natural elements $500 \mathrm{~m}$ & $-0.001 \pm 0.012$ & 0.003 & 0.958 \\
\hline \multirow{6}{*}{$\begin{array}{l}\text { Parataxonomic richness, } \\
3 \text { size classes }\end{array}$} & HNV overall index & $-0.039 \pm 0.063$ & 0.368 & 0.544 \\
\hline & Crop diversity & $0.031 \pm 0.205$ & 0.023 & 0.878 \\
\hline & Extensive farming practices & $-0.074 \pm 0.187$ & 0.153 & 0.696 \\
\hline & Semi-natural element availability & $-0.107 \pm 0.110$ & 0.880 & 0.348 \\
\hline & Proportion of semi-natural elements $100 \mathrm{~m}$ & $0.003 \pm 0.007$ & 0.149 & 0.700 \\
\hline & Proportion of semi-natural elements $500 \mathrm{~m}$ & $0.003 \pm 0.012$ & 0.054 & 0.816 \\
\hline \multirow{6}{*}{$\begin{array}{l}\text { Parataxonomic richness, } \\
7 \text { size classes }\end{array}$} & HNV overall index & $-0.056 \pm 0.079$ & 0.487 & 0.485 \\
\hline & Crop diversity & $0.017 \pm 0.255$ & 0.005 & 0.946 \\
\hline & Extensive farming practices & $-0.183 \pm 0.229$ & 0.613 & 0.434 \\
\hline & Semi-natural element availability & $-0.113 \pm 0.140$ & 0.644 & 0.422 \\
\hline & Proportion of semi-natural elements $100 \mathrm{~m}$ & $0.008 \pm 0.009$ & 0.675 & 0.411 \\
\hline & Proportion of semi-natural elements $500 \mathrm{~m}$ & $0.013 \pm 0.015$ & 0.670 & 0.413 \\
\hline \multirow[t]{6}{*}{ Genus dominance } & HNV overall index & $-0.035 \pm 0.016$ & 4.903 & $0.027^{*}$ \\
\hline & Crop diversity & $-0.166 \pm 0.050$ & 9.862 & $\mathbf{0 . 0 0 2} * *$ \\
\hline & Extensive farming practices & $-0.104 \pm 0.051$ & 4.014 & $0.045^{*}$ \\
\hline & Semi-natural element availability & $-0.034 \pm 0.028$ & 1.411 & 0.235 \\
\hline & Proportion of semi-natural elements $100 \mathrm{~m}$ & $0.004 \pm 0.003$ & 3.067 & 0.080 \\
\hline & Proportion of semi-natural elements $500 \mathrm{~m}$ & $0.002 \pm 0.004$ & 0.213 & 0.644 \\
\hline \multirow{6}{*}{$\begin{array}{l}\text { Parataxonomic } \\
\text { dominance, } 3 \text { size } \\
\text { classes }\end{array}$} & HNV overall index & $-0.039 \pm 0.017$ & 4.870 & $0.027 *$ \\
\hline & Crop diversity & $-0.181 \pm 0.056$ & 9.804 & $0.002 * *$ \\
\hline & Extensive farming practices & $-0.091 \pm 0.057$ & 2.499 & 0.114 \\
\hline & Semi-natural element availability & $-0.043 \pm 0.031$ & 1.946 & 0.163 \\
\hline & Proportion of semi-natural elements $100 \mathrm{~m}$ & $0.005 \pm 0.003$ & 2.618 & 0.106 \\
\hline & Proportion of semi-natural elements $500 \mathrm{~m}$ & $0.003 \pm 0.005$ & 0.331 & 0.565 \\
\hline \multirow{6}{*}{$\begin{array}{l}\text { Parataxonomic } \\
\text { dominance, } 7 \text { size } \\
\text { classes }\end{array}$} & HNV overall index & $-0.015 \pm 0.011$ & 1.913 & 0.167 \\
\hline & Crop diversity & $-0.049 \pm 0.037$ & 1.750 & 0.186 \\
\hline & Extensive farming practices & $-0.031 \pm 0.036$ & 0.763 & 0.382 \\
\hline & Semi-natural element availability & $-0.025 \pm 0.020$ & 1.566 & 0.211 \\
\hline & Proportion of semi-natural elements $100 \mathrm{~m}$ & $0.003 \pm 0.002$ & 2.695 & 0.101 \\
\hline & Proportion of semi-natural elements $500 \mathrm{~m}$ & $0.001 \pm 0.003$ & 0.126 & 0.723 \\
\hline
\end{tabular}

$\mathrm{n}=70$ collections and $d f=1$ in all cases. Significant $P$-values are indicated in bold $(* P \leq 0.05 ; * * P \leq 0.01)$. Models contained an assemblage-level attribute as the response variable, an environmental variable as fixed effects, and school, municipality and sampling site identities as a suite of hierarchically nested random effects. In each case, the first four environmental variables were derived from the High Nature Value data and calculated at the municipality level. The proportion of herbaceous semi-natural elements was derived from Corine Land Cover data (2006) and calculated at two spatial scales (100 and $500 \mathrm{~m}$ radius centred on sampling sites)

et al. 2011; Goulson et al. 2015). The national scale often has the advantage of representing both a large scale from an ecological point of view and a policy-relevant scale for the future implementation of conservation measures (Woodcock et al. 2014; Budge et al. 2015). Citizen science programs have been proven to be very useful tools for such purposes (Devictor et al. 2010; Dickinson et al. 2010). Regarding bees, we showed that citizen science programs combining the collection of biological material by a targeted network of citizens and the identification to species level 


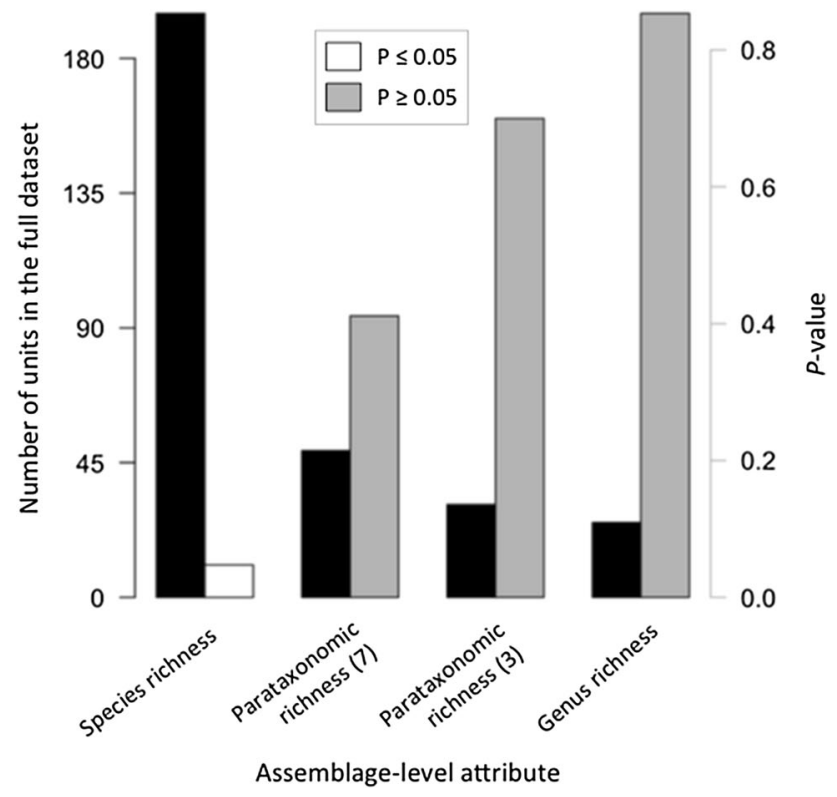

Fig. 4 Number of units for species richness and for alternative (para) taxonomic attributes (black bars), and $P$-value for the generalized linear mixed model including the assemblage-level attribute and the proportion of herbaceous semi-natural elements in $100 \mathrm{~m}$ radius windows as environmental variable (see Tables 1,2 for details). The white bar denotes a significant result $(P \leq 0.05)$ whilst the grey bars denote nonsignificant results. 'Parataxonomic richness (7)' and 'Parataxonomic richness (3)' are richness measures based on either 7 or 3 subdivisions of the inter-tegular distance (which is used as a surrogate for body size)

(often crucial for most conservation issues) by expert bee taxonomists could provide relevant results to guide conservation measures at a national scale. Moreover, through the involvement of agricultural high schools, our study focused on agricultural landscapes where bee conservation has been proven to be essential because of the large areas they occupy and the benefits of bee pollination on entomophilous crops (Deguines et al. 2012).

Acknowledgments Our first thanks go to all the biology and ecology teachers and technicians who took an active and enthusiastic part in this study: Jérôme Bangardi, Cécile Bella-Olémé, Jean-Gabriel Borrely, Annick Bourrouillou, Xavier Bunker, Chrystelle Cambrouse, Alexandre Chambert, Marie-Pierre Chevallet, Jean-Michel Cholet, Jean-Louis Ciblas, Roland Commerçon, Flora Couturier, Sophie Coyac, Vincent Dufraisse, Patrice Duhamel, Marie-Christine Fingier, Christophe Fraisse, Patrick Golfier, Véronique Graff-Chambolle, Thomas Guilloux, Sébastien Hoguet, Laurent Houedry, Marie Isaac, Renaud Jégat, Franck Leprince, Christophe Levesque, Dominique Malécot, Mireille Monnier, Dominique Paris, Christophe Philippe, Julien Plaisse, Laurence Rosain, Lise Saint-Arroman, Nathalie Sérès, Jan Siess, Christel Simon, Eric Van de Pitte, Karine Voogden. We also thank Jean-Pierre Débrosse, Louis-Marie Voisin, and Jean-Luc Toullec who helped in establishing and coordinating the network. We thank the specialists who identified bee specimens: Holger Dathe, Eric Dufrêne, David Genoud, Gérard Le Goff, Gilles Mahé, Denis Michez, Alain Pauly, Stephan Risch, Erwin Scheuchl, and Robert Fonfria †. Further thanks are due to Eric Dufrêne, David Genoud, Denis Michez and Nicolas Vereecken for help with the teaching of bee biology and taxonomy to the teachers and technicians. We also warmly thank Matthieu Aubert, Stan Chabert, Laura Fortel, Benoît Geslin, and Arnaud Le Nevé for fruitful discussions, Marie-Josée Buffière, Anne Laure Guirao, Nicolas Morison, and Céline Pleindoux for their assistance in the laboratory, and Philippe Pointereau (Solagro, http://www. solagro.org) for providing the data for the High Nature Value indicator. We are grateful to two anonymous referees for their constructive comments. This research was funded in part by the European Social Fund of the European Union administered by the Bergerie Nationale, by the French Ministries in charge of Ecology and Agriculture (Biodivea program) and by the not-for-profit organisation Pollinis (http:// www.pollinis.org).

Open Access This article is distributed under the terms of the Creative Commons Attribution 4.0 International License (http://creativecommons.org/licenses/by/4.0/), which permits unrestricted use, distribution, and reproduction in any medium, provided you give appropriate credit to the original author(s) and the source, provide a link to the Creative Commons license, and indicate if changes were made.

\section{References}

Amiet F, Müller A, Neumeyer R (1999) Apidae 2: Colletes, Dufourea, Hylaeus, Nomia, Nomioides, Rhophitoides, Rophites, Sphecodes, Systropha. p 219

Amiet F, Herrmann M, Müller A, Neumeyer R (2001) Apidae 3: Halictus, Lasioglossum. p 208

Amiet F, Herrmann M, Müller A, Neumeyer R (2004) Apidae 4: Anthidium, Chelostoma, Coelioxys, Dioxys, Heriades, Lithurgus, Megachile, Osmia, Stelis. Centre Suisse de Cartographie de la Faune. p 273

Amiet F, Herrmann M, Müller A, Neumeyer R (2007) Apidae 5: Ammobates, Ammobatoides, Anthophora, Biastes, Ceratina, Dasypoda, Epeoloides, Epeolus, Eucera, Macropis, Melecta, Melitta, Nomada, Pasites, Tetralonia, Thyreus, Xylocopa. p 356

Amiet F, Herrmann M, Müller A, Neumeyer R (2010) Apidae 6: Andrena, Melitturga, Panurginus, Panurgus. p 316

Banaszak J, Banaszak-Cibicka W, Szefer P (2014) Guidelines on sampling intensity of bees (Hymenoptera: Apoidea: Apiformes). J Insect Conserv 18:651-656

Bates D, Maechler M, Bolker B, Walker S (2014) lme4: Linear mixedeffects models using Eigen and S4. R package version 1.1-7. http://CRAN.R-project.org/package $=1 \mathrm{me} 4 \& \mathrm{gt}$

Baum KA, Wallen KE (2011) Potential bias in pan trapping as a function of floral abundance. J Kans Entomol Soc 84:155-159

Biesmeijer JC, Roberts SPM, Reemer M, Ohlemüller R, Edwards M, Peeters T, Schaffers AP, Potts SG, Kleukers R, Thomas CD, Settele J, Kunin WE (2006) Parallel declines in pollinators and insect-pollinated plants in Britain and the Netherlands. Science 313:351-354

Birkin L, Goulson D (2015) Using citizen science to monitor pollination services. Ecol Entomol 40(Suppl 1):3-11

Bonney R, Cooper CB, Dickinson J, Kelling S, Phillips T, Rosenberg KV, Shirk J (2009) Citizen science: a developing tool for expanding science knowledge and scientific literacy. Bioscience 59:977-984

Bossard M, Heymann Y, Lenco M, Steenmans C (2006) CORINE Land cover. http://www.eea.europa.eu/publications/COR0-landcover. Accessed 10 Oct 2014

Brown MJF, Paxton RJ (2009) The conservation of bees: a global perspective. Apidologie 40:410-416

Budge GE, Garthwaite D, Crowe A, Boatman ND, Delaplane KS, Brown MA, Thygesen HH, Pietravalle S (2015) Evidence for pollinator cost and farming benefits of neonicotinoid seed coatings on oilseed rape. Sci Rep 5:12574 
Butchart SHM, Walpole M, Collen B, van Strien A, Scharlemann JPW, Almond REA et al (2010) Global biodiversity: indicators of recent declines. Science 328:1164-1168

Cane JH (1987) Estimation of bee size using intertegular span (Apoidea). J Kans Entomol Soc 60:145-147

Cardoso P, Erwin TL, Borges PAV, New TR (2011) The seven impediments in invertebrate conservation and how to overcome them. Biol Conserv 144:2647-2655

Caruso T, Pigino G, Bernini F, Bargagli R, Migliorini M (2007) The Berger-Parker index as an effective tool for monitoring the biodiversity of disturbed soils: a case study on Mediterranean oribatid (Acari: Oribatida) assemblages. Biodivers Conserv 16:3277-3285

Casanovas P, Lynch HJ, Fagan WF (2014) Using citizen science to estimate lichen diversity. Biol Conserv 171:1-8

CEC (2006) Development of agri-environmental indicators for monitoring the integration of environmental concerns into the common agricultural policy. Communications from the commission to the council and European Parliament, Brussels

Deguines N, Julliard R, de Flores M, Fontaine C (2012) The whereabouts of flower visitors: contrasting land-use preferences revealed by a country-wide survey based on citizen science. PLoS One 7(9):e45822

Deguines N, Jono C, Baude M, Henry M, Julliard R, Fontaine C (2014) Large-scale trade-off between agricultural intensification and crop pollination services. Front Ecol Environ 12:212-217

Devictor V, Whittaker RJ, Beltrame C (2010) Beyond scarcity: citizen science programmes as useful tools for conservation biogeography. Divers Distrib 16:354-362

Dickinson JL, Zuckerberg B, Bonter DN (2010) Citizen science as an ecological research tool: challenges and benefits. Annu Rev Ecol Evol Syst 41:149-172

Diekötter T, Kadoya T, Peter F, Wolters V, Jauker F (2010) Oilseed rape crops distort plant-pollinator interactions. J Appl Ecol 47:209-214

Doxa A, Paracchini ML, Pointereau P, Devictor V, Jiguet F (2012) Preventing biotic homogenization of farmland bird communities: the role of High Nature Value farmland. Agric Ecosyst Environ 148:83-88

European Union (2013) Overview of CAP reform 2014-2020. Agricultural Policy Perspectives Brief 5:1-10

Fortel L, Henry M, Guilbaud L, Guirao AL, Kuhlmann M, Mouret H, Rollin O, Vaissière BE (2014) Decreasing abundance, increasing diversity and changing structure of the wild bee community (Hymenoptera: Anthophila) along an urbanization gradient. PLoS One 9:e104679

Gardiner MM, Allee LL, Brown PMJ, Losey JE, Roy HE, Smyth RR (2012) Lessons from lady beetles: accuracy of monitoring data from US and UK citizen-science programs. Front Ecol Environ 10:471-476

Garibaldi LA, Carvalheiro L, Vaissière BE, Gemmill-Herren B, Hipólito J, Freitas BM, Ngo HT, Azzu N, Sáez A, Aström J, An J, Blochtein B, Buchori D, Chamorro Garcia FJ, Oliveira da Silva F, Devkota K, Fátima Ribeiro M, Freitas L, Gaglianone MC, Goss M, Irshad M, Kasina M, Pacheco Filho AJS, Piedade Kiill LH, Kwapong P, Parra GN, Pires C, Pires V, Rawal RS, Rizali A, Saraiva AM, Veldtman R, Viana BF, Witter S, Zhang H (2016) Mutually beneficial pollinator diversity and crop yield outcomes in small and large farms. Science 352:387-391

Gathmann A, Tscharntke T (2002) Foraging ranges of solitary bees. J Anim Ecol 71:757-764

González-Varo JP, Biesmeijer JC, Bommarco R, Potts SG, Schweiger O, Smith HG, Steffan-Dewenter I, Szentgyörgyi H, Woyciechowski M, Vilá M (2013) Combined effects of global change pressures on animal-mediated pollination. Trends Ecol Evol 28:524-530
Goulson D, Nicholls E, Botias C, Rotheray EL (2015) Combined stress from parasites, pesticides and lack of flowers drives bee declines. Science. doi:10.1126/science.1255957

Hillebrand H, Bennett DM, Cadotte MW (2008) Consequences of dominance: a review of evenness effects on local and regional ecosystem processes. Ecology 89:1510-1520

Kerr JT, Kharouba HM, Currie DJ (2007) The macroecological contribution to global change solutions. Science 316:1581-1584

Krell F-T (2004) Parataxonomy vs. taxonomy in biodiversity studies-pitfalls and applicability of "morphospecies" sorting. Biodivers Conserv 13:795-812

Kremen C, M'Gonigle LK (2015) Small-scale restoration in intensive agricultural landscapes supports more specialized and less mobile pollinator species. J Appl Ecol. doi:10.1111/1365-2664.12418

Kremen C, Ullman KS, Thorp RW (2011) Evaluating the quality of citizen-scientist data on pollinator communities: citizen-scientist pollinator monitoring. Conserv Biol 25:607-617

Kuhlmann M, Ascher JS, Dathe HH, Ebmer AW, Hartmann P, Michez D, Müller A, Patiny S, Pauly A, Praz C, Rasmont P, Risch S, Scheuchl E, Schwarz M, Terzo M, Williams PH, Amiet F, Baldock D, Berg Ø, Bogusch P, Calabuig I, Cederberg B, Gogala A, Gusenleitner F, Josan Z, Madsen HB, Nilsson A, Ødegaard F, Ortiz-Sanchez J, Paukkunen J, Pawlikowski T, Quaranta M, Roberts SPM, Sáropataki M, Schwenninger HR, Smit J, Söderman G, Tomozei B (2015) Checklist of the Western Palaearctic Bees (Hymenoptera: Apoidea: Anthophila). http://westpalbees.myspecies.info. Accessed 17 Feb 2015

Le Féon V, Burel F, Chifflet R, Henry M, Ricroch A, Vaissière BE, Baudry J (2013) Solitary bee abundance and species richness in dynamic agricultural landscapes. Agric Ecosyst Environ 166:94-101

Le Féon V, Poggio SL, Torretta JP, Bertrand C, Molina GAR, Burel F, Baudry J, Ghersa CM (2016) Diversity and life-history traits of wild bees in intensive agricultural landscapes in the Rolling Pampa, Argentina. J Nat Hist 50:1175-1196

LeBuhn G, Droege S, Connor EF, Gemmill-Herren B, Potts SG, Minckley RL, Griswold T, Jean R, Kula E, Roubik DW, Cane J, Wright KW, Frankie G, Parker F (2013) Detecting insect pollinator declines on regional and global scales. Conserv Biol 27:113-120

Lye GC, Osborne JL, Park KJ, Goulson D (2012) Using citizen science to monitor Bombus populations in the UK: nesting ecology and relative abundance in the urban environment. J Insect Conserv 16:697-707

Marini L, Quaranta M, Fontana P, Biesmeijer JC, Bommarco R (2012) Landscape context and elevation affect pollinator communities in intensive apple orchards. Basic Appl Ecol 13:681-689

Marini L, Öckinger E, Bergman K-O, Jauker B, Krauss J, Kuussaari M, Pöyry J, Smith HG, Steffan-Dewenter I, Bommarco R (2014) Contrasting effects of habitat area and connectivity on evenness of pollinator communities. Ecography 37:544-551

McGill BJ, Etienne RS, Gray JS, Alonso D, Anderson MJ, Benecha HK, Dornelas M, Enquist BJ, Green JL, He F, Hurlbert AH, Magurran AE, Marquet PA, Maurer BA, Ostling A, Soykan CU, Ugland KI, White EP (2007) Species abundance distributions: moving beyond single prediction theories to integration within an ecological framework. Ecol Lett 10:995-1015

Michener CD (2007) The bees of the world, 2nd edn. The Johns Hopkins University Press, Baltimore

Miller-Rushing AM, Primack R, Bonney R (2012) The history of public participation in ecological research. Front Ecol Environ 10:285-290

Morandin LA, Kremen C (2013) Hedgerow restoration promotes pollinator populations and exports native bees to adjacent fields. Ecol Appl 23:829-839 
Moretti M, de Bello F, Roberts SPM, Potts SG (2009) Taxonomical vs. functional responses of bee communities to fire in two contrasting climatic regions. J Anim Ecol 78:98-108

Nieto A, Roberts SPM, Kemp J, Rasmont P, Kuhlmann M, García Criado M, Biesmeijer JC, Bogusch P, Dathe HH, De la Rúa P, De Meulemeester T, Dehon M, Dewulf A, Ortiz-Sánchez FJ, Lhomme P, Pauly A, Potts SG, Praz C, Quaranta M, Radchenko VG, Scheuchl E, Smit J, Straka J, Terzo M, Tomozii B, Window J, Michez D (2014) European red list of bees. Publication Office of the European Union, Luxembourg

Ollerton J, Erenler H, Edwards M, Crockett R (2014) Extinctions of aculeate pollinators in Britain and the role of large-scale agricultural changes. Science 346:1360-1362

Patiny S, Michez D, Rasmont P (2009) Survey of wild bees in WestPalaearctic region. Apidologie 40:313-331

Pisanty G, Mandelik Y (2015) Profiling crop pollinators: life-history traits predict habitat use and crop visitation by Mediterranean wild bees. Ecol Appl 25:742-752

Pocock MJO, Roy HE, Preston CD, Roy DB (2015) The Biological Records Centre: a pioneer of citizen science. Biol J Linnean Soc 115:475-493

Pointereau P, Coulon F, Doxa A, Paracchini ML, Terres J-M, Jiguet F (2010) Les systèmes agricoles à haute valeur naturelle en France métropolitaine. Courrier de l'environnement de l'INRA 59:3-18

R Core Team (2014) R: a language and environment for statistical computing. R Foundation for Statistical Computing, Vienna. http://www.R-project.org/

Rader R, Bartomeus I, Tylianakis JM, Laliberté E (2014) The winners and losers of land use intensification: pollinator community disassembly is non-random and alters functional diversity. Divers Distrib 20:908-917

Rollin O, Bretagnolle V, Fortel L, Guilbaud L, Henry M (2015) Habitat, spatial and temporal drivers of diversity patterns in a wild bee assemblage. Biodivers Conserv 24:1195-1214

Roulston TH, Smith SA, Brewster AL (2007) A comparison of pan trap and intensive net sampling techniques for documenting a bee (Hymenoptera: Apiformes) fauna. J Kans Entomol Soc 80:179-181

Roy DB, Ploquin EF, Randle Z, Risely K, Botham MS, Middlebrook I, Noble D, Cruickshanks K, Freeman SN, Brereton TM (2015) Comparison of trends in butterfly populations between monitoring schemes. J Insect Conserv 19:313-324

Saunders ME, Luck GW (2014) Spatial and temporal variation in pollinator community structure relative to a woodland-almond plantation edge. Agric Forest Entomol 16:369-381

Schmeller DS, Henry PY, Julliard R, Gruber B, Clobert J, Dziock F, Lengyel S, Nowicki P, Déri E, Budrys E (2009) Advantages of volunteer based biodiversity monitoring in Europe. Conserv Biol 23:307-316

Sheffield CS, Pindar A, Packer L, Kevan PG (2013) The potential of cleptoparasitic bees as indicator taxa for assessing bee communities. Apidologie 44:501-510
Steffan-Dewenter I, Potts SG, Packer L (2005) Pollinator diversity and crop pollination services are at risk. Trends Ecol Evol 20:651-652

Thomas JA, Edwards M, Simcox DJ, Powney GD, August TA, Isaac NJB (2015) Recent trends in UK insects that inhabit early successional stages of ecosystems. Biol J Linnean Soc 115:636-646.

Tolkkinen M, Mykrä H, Markkola A-M, Aisala H, Vuori K-M, Lumme J, Pirttilä AM, Muotka T (2013) Decomposer communities in human-impacted streams: species dominance rather than richness affects leaf decomposition. J Appl Ecol 50:1142-1151

van Rijn I, Neeson TM, Mandelik Y (2015) Reliability and refinement of the higher taxa approach for bee richness and composition assessments. Ecol Appl 25:88-98

van der Wal R, Anderson H, Robinson A, Sharma N, Mellish C, Roberts S, Darvill B, Siddharthan A (2015) Mapping species distributions: a comparison of skilled naturalist and lay citizen science recording. Ambio 44(Suppl 4):S584-S600

Vaughan M, Vaissière BE, Maynard G, Kasina M, Nocelli RCF, ScottDupree C, Johansen E, Brittain C, Coulson M, Dinter A (2014) Overview of non-Apis bees. In: Fischer D, Moriarty T (eds) Pesticide risk assessment for pollinators. Wiley Blackwell, Hoboken

Westphal C, Bommarco R, Carré G, Lamborn E, Morison N, Petanidou T, Potts SG, Roberts SPM, Szentgyörgyi H, Tscheulin $\mathrm{T}$, Vaissière BE, Woyciechowski M, Biesmeijer JC, Kunin WE, Settele J, Steffan-Dewenter I (2008) Measuring bee diversity in different European habitats and biogeographical regions. Ecol Monogr 78:653-671

Westrich P (1989) Die Wildbienen Baden-Württembergs Spezieller Teil. Eugen Ulmer, Stuttgart, p 536

Williams NM, Minckley R, Silviera F (2001) Variation in native bee faunas and its implications for detecting community changes. Conserv Ecol 5:7.

Williams NM, Crone EE, Roulston TH, Minckley RL, Packer L, Potts SG (2010) Ecological and life-history traits predict bee species responses to environmental disturbances. Biol Conserv 143:2280-2291

Wilson JS, Griswold T, Messinger OJ (2008) Sampling bee communities (Hymenoptera: Apiformes) in a desert landscape: are pan traps sufficient? J Kans Entomol Soc 81:288-300

Winfree R, Bartomeus I, Cariveau DP (2011) Native pollinators in anthropogenic habitats. Annu Rev Ecol Evol Syst 42:1-22

Wood TJ, Holland JM, Goulson D (2015) A comparison of techniques for assessing farmland bumblebee populations. Oecologia 177:1093-1102

Woodcock BA, Harrower C, Redhead J, Edwards M, Vanbergen AJ, Heard MS, Roy DB, Pywell RF (2014) National patterns of functional diversity and redundancy in predatory ground beetles and bees associated with key UK arable crops. J Appl Ecol $51: 142-151$ 